Jurnal Indonesia Sosial Teknologi:p-ISSN: 2723 - 6609

e-ISSN :2745-5254

Vol. 2, No.12 Desember 2021

\title{
IMPLEMENTASI KEBIJAKAN PENINGKATAN DAYA SAING UMKM DENGAN PROGRAM PELATIHAN INTERNET MARKETING DI KOTA JAKARTA (STUDI PADA DINAS KOPERASI DAN UMKM)
}

\author{
Dessica Dwiyuliana ${ }^{1}$, Renie Dwi Sulistyani ${ }^{2}$, Zulfikar Abdulah ${ }^{3}$, Augustin Rina \\ Herawati $^{4}$ \\ Politeknik STIA LAN Jakarta ${ }^{1,2,3,4}$ \\ Email: dessicad9794@gmail.com ${ }^{1}$, reniedwisulistyani@gmail.com ${ }^{2}$, \\ zulfikarabdulahzulf@gmail.com³ ${ }^{3}$.
}

\begin{abstract}
Abstrak
Tujuan dari penelitian ini adalah untuk mengetahui Implementasi kebijakan peningkatan daya saing UMKM dengan program pelatihan internet marketing di kota jakarta (Studi pada dinas koperasi dan UMKM). Penelitian ini adalah kualitatif karena peneliti mencoba menganalisis serta mengimplementasikan hubungan antar variabel dan menginterpretasikan hasilnya. Objek yang digunakan dalam penelitian ini adalah kebijakan UKM Pemerintah Kota jakarta. Data survei digunakan untuk data sekunder, wawancara, dan studi pustaka yang diperoleh dari situs resmi Pemerintah Kota jakarta. Berdasarkan penelitian yang tekag dilakukan didapatkan hasil bahwa Strategi Pelatihan digital marketing sangat baik dan sangat membantu bagi para pelaku UMKM dan koperasi karena menambah wawasan atau pengetauan tentang cara mengembangkan usahanya dalam meningkatkan daya saing serta meningkatkan pendapatannya. Dengan adanya program pelatihan para pelaku UMKM menjadi terbantu dan mempunyai tempat untuk belajar atau sharing tentang usahanya.
\end{abstract}

Kata kunci: peningkatan daya saing; pelatihan; internet marketing; UMKM

\section{Abstract}

The purpose of this study was to determine the implementation of policies to increase the competitiveness of MSMEs with internet marketing training programs in the city of Jakarta (Studies on cooperatives and MSMEs). This research is qualitative becausethe researcher tries to analyze and implement the relationship between variables andinterpret the results. The object used in this research is the SME policy of the Jakarta City Government. Survey data is used for secondary data, interviews, and literaturestudies obtained from the official website of the Jakarta City Government. Based onthe research that has been carried out, the results show that the digital marketing training strategy is very good and very helpful for SMEs and cooperatives because itadds insight or knowledge about how to develop their business in increasing competitiveness and increasing their income. With the training program, MSME actors will be helped and have a place to learn or share about their business.

Keywords: increasing competitiveness; training; internet marketing; MSME 


\section{Pendahuluan}

Implementasi kebijakan adalah bagian dari rangkaian proses kebijakan publik. Proses kebijakan adalah suatu rangkaian tahap yang saling bergantung yang diatur menurut urutan waktu, penyusunan agenda, formulasi kebijakan adopsi kebijakan dan penilaian kebijakan. Implementasi kebijakan merupakan faktor penting dalam sebuah kebijakan. Di mana implementasinya sebuah kebijakan akan mengandung resiko kegagalan bila tidak terimplementasikan dengan baik (Maesaroh, 2020).

UMKM merupakan usaha yang bersifat padat karya, tidak membutuhkan persyaratan tertentu seperti tingkat pendidikan, keahlian (keterampilan) pekerja, dan penggunaan modal usaha relatif sedikit serta teknologi yang digunakan cenderung sederhana(Kusnadi et al., 2020). Usaha mikro adalah usaha produktif milik perorangan atau badan usaha perorangan yang memenuhi kriteria, usaha kecil adalah usaha ekonomi produktif yang berdiri sendiri yang dilakukan oleh perorangan atau badan usaha yang merupakan anak perusahaan atau bukan cabang yang dimiliki, di kuasai, atau menjadi bagian baik langsung maupun tidak langsung dari usaha menengah atau besar yang memenuhi kriteria usaha kecil. Usaha menengah adalah usaha ekonomi produktif yang berdiri sendiri yang dilakukan oleh perorangan atau badan usaha yang bukan merupakan anak\ perusahaan atau cabang perusahaan yang di miliki, di kuasai, atau menjadi bagian baik langsung maupun tidak langsung dengan usaha kecil atau usaha besar dengan jumlah kekayaan bersih atau hasil penjualan tahunan (Kholidah \& Hakim, 2018).

Kebijakan UMKM di atur dalam regulasi tersendiri yaitu UU Nomor 20 tahun 2008 yang menjelaskan mengenai peraturan - peraturan UMKM. Kriteria UMKM dijelaskan dalam UU tersebut bahwa dunia usaha di bedakan menjadi Usaha mikro, kecil, dan menengah. Segmentasi usaha mikro, kecil, dan menengah di golongkan secara khusus karena mewakili segmen rakyat kecil dengan sebutan usaha mikro, kecil, dan menengah (UMKM) (Lestari \& Taufiq, 2016). Berdasarkan UU tersebut UMKM adalah Usaha Produktif yang memenuhi kriteria usaha dengan Batasan tertentu kekayaan bersih dan hasil penjualan tahunan. Keberadaan UMKM ini tidak boleh dipandang sebelah mata. Umkm merupakan salah satu sektor strategis dalam perekonomian nasional. Tujuan UMKM yaitu menumbuhkan dan mengembangkan usahanya dalam rangka membangun perekonomian nasional berdasarkan demokrasi ekonomi yang berkeadilan. Perkembangan UMKM dari tahun ke tahun mulai berkembang pesat besarnya minat masyarakat untuk berwirausaha atau mengembangkan usahanya kembali sebagai mata pencaharian sangatlah besar(Purnamaningsih \& Wirtya, 2018).

Dalam menghadapi mekanisme pasar yang makin terbuka dan kompetitif, penguasaan pasar merupakan prasyarat untuk meningkatkan daya saing UKM. Agar dapat menguasai pasar, maka UKM perlu mendapatkan informasi dengan mudah dan cepat, baik informasi mengenai pasar produksi maupun pasar faktor produksi. Informasi tentang pasar produksi sangat diperlukan untuk memperluas jaringan pemasaran produk yang dihasilkan oleh UKM (Julisar \& Miranda, 2013). 
Lebih lanjut Julisar \& Miranda (2013), mengatakan bahwa Pemanfaatan internet memungkinkan Usaha Kecil dan Menengah melakukan pemasaran dengan tujuan pasar global, sehingga peluang menembus ekspor sangat mungkin. Julisar \& Miranda (2013), memberikan pendapat mengenai hal positif yang dapat diperoleh dengan memanfaatkan jaringan internet dalam mengembangkan usaha adalah (1) dapat mempertinggi promosi produk dan layanan melalui kontak langsung, kaya informasi, dan interaktif dengan pelanggan (2) menciptakan satu saluran distribusi bagi produk yang ada (3) biaya pengiriman informasi ke pelanggan lebih hemat jika dibandingkan dengan paket atau jasa pos (4) waktu yang dibutuhkan untuk menerima atau mengirim informasi sangat singkat, hanya dalam hitungan menit atau bahkan detik (Dawanto, 2015).

selain itu, internet juga memiliki beberapa daya tarik dan keunggulan bagi para konsumen maupun organisasi, misalnya dalam kenyamanan, akses 24 jam sehari, efisiensi, alternatif ruang maupun pilihan yang relatif "tak terbatas"e, personalisasi, sumber informasi potensial, dan lain-lain. Pengaruh globalisasi yang tak terelakkan mengakibtakan setiap organisasi bisnis termasuk juga UMKM harus berhadapan dengan kompetisi yang semakin kompleks. dilakukan sebelum implementasi. UMKM memiliki ciri yang khusus yaitu resiko kegagagalan bisnis yang besar, anggaran yang terbatas, dan pengambilan keputusan cenderung terpusat pada pemilik (Supriyati \& Iqbal, 2013).

Pengguna internet terbanyak berprofesi sebagai Pekerja Wiraswasta sebesar 82,2 juta atau $62 \%$. Urutan pengguna internet berikutnya berprofesi sebagai Ibu Rumah Tangga (IRT) sebesar 22 juta atau 16,6\%, sedangkan pada gambar 1.4, terlihat bahwa konten yang paling sering dijunjungi, pengguna internet paling sering mengunjungi web onlineshop sebesar 82,2 juta atau 62\%, dan konten social media yang paling banyak dikujungi adalah Facebook sebesar 71,6 juta pengguna atau 54\% dan urutan kedua adalah Instagram sebesar 19,9 juta pengguna atau 15\%. (Statistik Pengguna Internet Indonesia 2016, Badan Pusat Statistik, 2016)

(Nasution et al., 2017; Sukarsih et al., 2016) menyatakan bahwa peserta UMKM setelah diberikan pelatihan dan pendampingan internet marketing, pengetahuan dan kemampuan pengrajin UKM tentang pemanfaatan teknologi internet sebagai media pemasaran online meningkat. Perkembangan UMKM yang ada saat ini harus diimbangi dengan adanya daya saing dari setiap UMKM, sehingga UMKM dapat bertahan dan berhasil menhadapi tantangan dan persaingan yang ada. Kemudian (Mujiyana et al., 2012) mengatakan bahwa salah satu daya saing yang harus dimiliki oleh UMKM adalah penguasaan teknologi informasi, kegiatan promosi atas suatu produk akan lebih optimal hasilnya apabila program periklanan yang dilakukan pada media internet juga diimbangi dengan tingginya pemasaran melalui e-mail, maka pemprosesan informasi oleh konsumen akan semakin baik. Pemakaian Teknologi Informasi (IT) dalam memasarkan produk UKM telah berhasil dikembangkan oleh sejumlah Negara seperti Cina, Jepang, dan India. Bahkan Konfederasi Industri India atau Confedration of Indian Industry (CII) merilis hasil survey yang memperlihatkan bahwa peranan Teknologi Informasi (IT) telah mengubah peruntungan sigmen UKM di India. Menurut hasil survey tersebut penggunaan IT di kalangan UKM telah menghasilkan peningkatan pendapatan yang signifikan, yakni 
$78 \%$ dari responden mengindekasikan peningkatan pendapatan akibat penggunaan IT (Jauhari, 2010).

Menteri Koperasi dan UKM Teten Masduki menegaskan, untuk mendukung Koperasi Modern, pelaku usaha mikro kecil dan menengah (UMKM) Naik kelas dan Wirausaha Produktif, perlu adanya dukungan dari berbagai pihak, termasuk sinergi lintas Kementerian/Lembaga (K/L). Teten berharap, pelatihan digitalisasi yang diselenggarakan sejak Agustus hingga November 2021 ini, dapat diimplementasikan dengan baik oleh para peserta sehingga bisa menjadi wirausaha yang adaptif, inovatif, dan berbasis teknologi (Sedyastuti, 2018). Program tersebut juga melatih kemampuan para peserta untuk memanfaatkan teknologi mulai dari yang paling sederhana, yakni membiasakan diri mengisi absensi digital hingga mengikuti kelas pembinaan secara daring. Kemudian, pelatihan dilanjutkan dengan pemberian materi digital yang lebih kompleks, misalnya bagaimana membuat desain produk sederhana secara mandiri dengan menggunakan aplikasi desain, membuat materi promosi sendiri, hingga lebih menarik dalam hal pemasaran.

Penelitian ini akan lebih mengelaborasi kebijakan peningkatan daya saing UMKM dengan program pelatihan internet marketing. Beberapa studi terdahulu mengulas bahwa pelaku UMKM beralih pada pemanfaatan teknologi digital termasuk media sosial untuk pengembangan UMKM di Indonesia (Purwana et al., 2017) (Erick Karunia et al., 2021). Sedangkan penelitian ini lebih pada upaya mempertegas kebijakan peningkatan daya saing UMKM dengan program pelatihan internet marketing. Pengembangan ini juga meliputi pemanfaatan, market place, media sosial, dan berbagai aplikasi pendukung lainnya serta dengan melakukan pelatihan terhadap mitra UMKM dan koperasi untuk dapat memanfaatkan media online dalam meningkatkan daya saing serta memasarkan dan memperkenalkan produknya kepada konsumen atau masyarakat luas

\section{Metode Penelitian}

Jenis penelitian ini adalah kualitatif karena peneliti mencoba menganalisis serta mengimplementasikan hubungan antar variabel dan menginterpretasikan hasilnya. Karena terdapat hubungan kausal antara variabel bebas (variabel terpengaruh) dan variabel terikat (variabel terpengaruh), penelitian ini pada dasarnya bersifat kausal. Penelitian dilakukan di kota Jakarta (Sugiyono., 2017). Objek yang digunakan dalam penelitian ini adalah kebijakan UKM Pemerintah Kota jakarta. Data survei digunakan untuk data sekunder, wawancara, dan studi pustaka yang diperoleh dari situs resmi Pemerintah Kota Jakarta. Teknik analisis data dilakukan dengan menginterpretasikan data

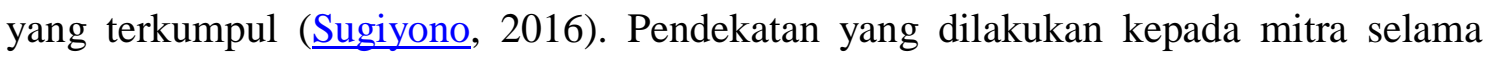
Program Kemitraan Masyarakat ini dengan cara

1. Metode Kebutuhan Belajar (Learning Needs Based). Sumber informasi tentang kebutuhan belajar peserta atau calon peserta. Pentingnya metode ini akan didasarkan kepada atas asumsi bahwa peserta akan belajar secara ekfektif bila semua komponen pembelajaran dapat membantu mereka untuk memenuhi kebutuhannya. 
2. Berorientasi pada tujuan kegiatan belajar (Learning Goals and Objective) . Tujuan belajar disusun bersama sumber belajar bersama peserta, potensi yang dimiliki serta sumber-sumber yang tersedia di lingkungan kehidupan mereka serta kemungkinan hambatan-hambatan yang muncul dalam kegiatan pembelajaran.

3. Berpusat pada peserta (Participant Centre). Peserta diikutsertakan dan harus berperan aktif dalam kegaitan perencanaan, pelaksanaan, dan evaluasi, mereka tidak hanya menjawab pertanyaan-pertanyaan yang berhubungan dengan kebutuhan belajar atau evaluasi belajar, akan tetapi beperan dalam merumuskan alat-alat instrument yang digunakan untuk kegiatan pembelajaran, dan ikut mengembangkan bahan pembelajaran

\section{Hasil dan Pembahasan}

Perkembangan teknologi digital memungkinkan para pelaku UMKM dan koperasi untuk memasarkan produknya secara online dan melakukan transaksi melalui sistem perbankan secara online pula(Purwana, Rahmi, \& Aditya, 2017). Diera Globalisasi seperti sekarang kemajuan zaman sudah semakin berkembang segala sesuatu bisa dilakukan menggunakan media internet tidak terkecuali dengan perdagangan atau bisnis jga memanfaatkan media online untuk memasarkan dan memperkenalkan produknya kepada konsumen atau masyarakat luas. Dengan adanya media komunikasi dan informasi sarana dan prasarana yang memadai pelaku usaha mikro dapat mempromosikan produkproduk yang telah dibuat kepada konsumen baik dalam kota dan luar kota. Hasil penelitian tersebut dikuatkan dengan teori Philp Kotler, yang menyatakan bahwa Pemasaran merupakan interaksi yang berusaha untuk menciptakan hubungan pertukaran. Tetapi pemasaran bukanlah suatu cara yang sederhana yang tidak sekedar untuk menghasilkan penjualan saja, pemasaran umumnya memiliki fungsi untuk menjadi jembatan yang menghubungkan produsen dengan konsumen untuk melakukan pertukaran yang saling menguntungkan bagi kedua belah pihak yang didukung dengan strategistrategi yang terdiri dari elemenelemen yang saling berhubungan, yaitu elemen kualitas produk, harga, promosi dan distribusi(Kotler \& Keller, 2016).

Dampak dari program-program yang telah berikan sangat baik dan sangat membantu bagi para pelaku usaha untuk mengembangkan usahanya maupun untuk menyelesaikan permasalahan yang dihadapi ketika mengembangkan usahanya, salah satu dari beberapa program yang dinas berikan yaitu program pelatihan pemasaran Online, banyak para pelaku usaha merasakan dampak nya setelah mengikuti program yang dinas berikan itu seperti produknya lebih banya dikenal masyarakat luas, pesanan semakin bertambah dan paling penting pendapatan menjadi meningkat(Ariyanto et al., 2021). Keuntungan yang diperoleh dari pemasaran online adalah biayanya murah akses atau pengunaannya mudah serta bisa memasarkan produk selama 24 jam dan bisa berkomunikasi langsung atara konsumen dan produsen tanpa bertemu atau bertatap muka. Jadi pemasaran online lebih hemat biaya dan waktu karena tidak perlu keliling-keliling untuk memasarkan produknya. Dampak secara sederhana bisa diartikan sebagai pengaruh 
atau akibat. Dalam setiap keputusan atau tindakan yang diambil oleh seseorang selalu ada dampak tersendiri, baik itu dampak positif maupun dampak negatif. Dampak juga bisa diartikan sebagai proses lanjutan dari sebuah pelaksanaan pengawasan internal(Nirwana \& Biduri, 2021).

Berubahnya Digital Maidset, dan mampu memahami dari kemanfatan Teknologi Informasi (Digital marketing/ Distribusi), Hasil Pelatihan ini memahami bahwa Kemajuan teknologi telah membawa banyak perubahan pada peradaban manusia. Hal ini membawa trend baru dimana hampir semua orang selalu memanfaatkan teknologi seperti berkomunikasi melalui media sosial, berbelanja lewat e-commerce atau mencari tahu informasi lewat internet. Mitra mulai menyadari kekuatan yang muncul dibalik perkembangan teknologi Informasi ini,serta mitra memahami jenis - jenis digital marketing dan tujuan masing - masing seperti: SMS Marketing, E-mail Marketing,Search Engine Marketing, Social Media Marketing, dan Content Marketing(Erick Karunia et al., 2021)

Hal penting dalam Pengembangan Digital Marketing Pada usaha Kecil di kota jakarta melalui program ini adalah pentingnya pemahaman semua pelaku usaha mengenai proses dan tahapan dalam Teknologi Informasi ECommerce dan Digital Marketing perlu menyeseuaikan dengan jenis usaha, dan target pasar. Pembelajaran lain adalah pentingnya perubahan pola pikir Maind Set dan perilaku khususnya Digital Maidset merupakan sudah keharusan untuk jaman sekarang atau Masa Industri 4.0 ini, dan terlebih adanya dampak Covid 19. setiap program penerapan Teknologi Informasi tidak akan berhasil. Pembelajaran selanjutnya adalah pengelola program harus senantiasa memiliki keluwesan atau fleksibel di dalam menjalankan program, mampu mendekati pemangku kepentingan dengan pendekatan kultural dan empati khususnya pada pelaku usaha kecil. Hasil program dalam bentuk hasil langsung atau keluaran (output), hasil tidak langsung (outcome) dan dampak sudah terasa bagi para penerima manfaat. Keberlangsungan program dapat terus dilaksanakan untuk meningkatkan Kontribusi Usaha Kecil kepada Berbagi Pihak(Purwana et al., 2017).

Tim pelatihan membantu UMKM dan Koperasi untuk menedesain website atau Toko Online yang bisa digunakan untuk meningkatkan daya saing penjualan, sehingg hasil dan luaran yang dicapai setelah pelaksanaan pelatihan bagi mitra umkm dan koperasi adalah Mempunyai website untuk promosi dan penjualan, Meningkatnya keterampilan dalam melakukan penjulan melalui internet, Peningkatan Motivasi dalam usaha mandiri(Jamiat \& Supyansuri, 2020).

Selain pelatihan Internet Marketing Mitra juga diajarkan bagaiamana memanajemen usaha dan diberikan pelatihan memasarkan produk melalui Internet Marketing sehingga kesulitan-kesulitan mitra selama ini dapat teratasi oleh Internet Marketing( Hendriadi, Sari, \& Padilah, 2019).

Dengan adanya website hasil dari Program Kemitraan Masyarakat dapat meningkatkan daya saing UMKM pada bidang Handycraft disamping itu juga dapat dengan cepat melakukan promosi keberbagai pelosok dunia, dan pangsa pasar luar negeri juga dapat di capai dengan adanya website toko online Handycraft. Toko online ini 
disesain sedemikian rupa untuk memudahkan konsumen dalam melakukan pembelian, dan disesain juga lebih sederhana agar Mitra mudah untuk menginput produk ke dalam Wesbsite. Dengan adanya Website hasil dari Program Kemitraan Masyarakat dapat meningkatkan daya saing UMKM. disamping itu juga dapat dengan cepat melakukan promosi keberbagai pelosok dunia, dan pangsa pasar luar negeri juga dapat di capai dengan adanya website Toko online Handycraft. Selain pelatihan Internet Marketing Mitra juga diajarkan bagaiamana memanajemen usaha dan diberikan pelatihan memasarkan produk melalui Internet Marketing sehingga kesulitan-kesulitan mitra

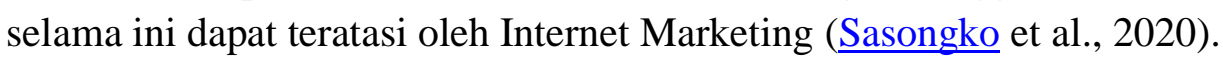

\section{Kesimpulan}

Berdasarkan hasil penelitian yang telah diuraikan dalam pembahasan, dapat disimpulkan bahwa Strategi Pelatihan digital marketing dalam meningkatkan meningkatkan daya saing yang diberikan kepada para pelaku UMKM dan koperasi dapat disimpulkan bahwa Strategi Pelatihan digital marketing sangat baik dan sangat membantu bagi para pelaku UMKM dan koperasi karena menambah wawasan atau pengetauan tentang cara mengembangkan usahanya dalam meningkatkan daya saing serta meningkatkan pendapatannya. Banyak para pelaku UMKM dan koperasi yang ingin mengembangkan usahanya tapi tidak tau caranya atau terkendala ketika akan mengembangkan usahanya. Dengan adanya program pelatihan para pelaku UMKM menjadi terbantu dan mempunyai tempat untuk belajar atau sharing tentang usahanya. Karena banyak para pelaku UMKM yang belum mengetahui tentang cara mengembangkan usahanya yang baik dan benar serta cara untuk memasarkan produknya melalui pemasaran online. 
Dessica Dwiyuliana, Renie Dwi Sulistyani, Zulfikar Abdulah, Augustin Rina Herawati

\section{Bibliografi}

Ariyanto, Aris, Wongso, Fery, Wijoyo, Hadion, Indrawan, Irjus, Musnaini, Akbar, Mada Faisal, Anggraini, Nia, Suherman, Suryanti, \& Devi, Wiara Sanchia Grafita Ryana. (2021). Strategi Pemasaran Umkm Di Masa Pandemi. In Strategi Pemasaran Umkm Di Masa Pandemi.

Badan Pusat Statistik, BPS Kota Medan. (2016). Statistik Daerah Kecamatan Medan Denai.

Dawanto, dan Ghalib Agfa Polnaya. (2015). Pengembangan ekonomi lokal untuk meningkatkan daya saing pada ukm ekonomi kreatif batik bakaran di Pati, Jawa Tengah. Jurnal Bisnis Dan Ekonomi (JBE).

Erick Karunia, Ahmad Juliana, Syahran, Ahmatang, Nurul Hidayat, Budi Hasyim, Muh. Irfandy Azis, \& Shalahuddin. (2021). Digital Marketing Training for UMKM of Tarakan City. International Journal of Community Service. https://doi.org/10.51601/ijcs.v1i2.3

Hendriadi, Ade Andri, Sari, Betha nurina, \& Padilah, Tesa Nur. (2019). Pelatihan Digital Marketing Usaha Mikro, Kecil dan Menengah (UMKM) di Kabupaten Karawang. J-Dinamika: Jurnal Pengabdian Masyarakat. https://doi.org/10.25047/jdinamika.v4i2.1133

Jamiat, Nuslih, \& Supyansuri, Cahyadi. (2020). Pemanfaatan Digital Marketing Pada Umkm Sukapura Dayeuhkolot Kabupaten Bandung. Atrabis. https://doi.org/10.38204/atrabis.v6i1.406

Jauhari, Jaidan. (2010). Upaya Pengembangan Usaha Kecil dan Menengah (UKM) dengan Memanfaatkan E-Commerce. Jurnal Sistem Informasi (JSI), 2017Janиа(43), 46-73. https://doi.org/10.4135/9781412964623.n403

Julisar, \& Miranda, Eka. (2013). Pemakaian E-Commerce Untuk Usaha Kecil dan Menengah guna Meningkatkan Daya Saing. 4(2), 638645.https://doi.org/10.21512/comtech.v4i2.2486

Kholidah, Nur, \& Hakim, Miftahur Rahman. (2018). Peluang dan Tantangan Pengembangan Usaha Mikro Kecil Menengah (UMKM) Dari Berbagai Aspek Ekonomi. Jurnal Ilmiah Manajemen Dan Bisnis.

Kotler, Philip, \& Keller, Kevin Lane. (2016). A framework for marketing management. Pearson Boston, MA.

Kusnadi, Iwan Henri, Natika, Luki, \& Alsonia, Dyera Octa. (2020). Implementasi Kebijakan Pembinaan UMKM di Kabupaten Subang. The World of Business Administration Journal. https://doi.org/10.37950/wbaj.v2i2.937 
Implementasi Kebijakan Peningkatan Daya Saing UMKM dengan Program Pelatihan Internet Marketing di Kota Jakarta (Studi pada Dinas Koperasi dan UMKM)

Lestari, P., \& Taufiq, A. (2016). Evaluasi Implementasi Kebijakan Pemberdayaan USAha Mikro Kecil Dan Menengah (UMKM) Di Kabupaten Kudus. Journal of Politic and Government ....

Maesaroh, Syti Sarah. (2020). Upaya Peningkatan Daya Saing Usaha Mikro, Kecil, dan Menengah (UMKM) Kota Tasikmalaya melalui Pemanfaatan System Informasi Geografis (SIG). JURNAL ILMU MANAJEMEN DAN BISNIS. https://doi.org/10.17509/jimb.v11i1.21148

Mujiyana, Mujiyana, Sularto, Lana, \& Mukhyi, M. A. (2012). Pengaruh Penerapan Periklanan Di Internet Dan Pemasaran Melalui E-Mail Produk UMKM Di Wilayah Depok.J@ti Undip, 7(3).https://doi.org/10.24114/jpkm.v23i2.7028

Nasution, Muhammad Irfan, Prayogi, Muhammad Andi, \& Nasution, Satria Mirsya Affandy. (2017). Pembinaan Pengelolaan Manajemen Usaha Dan E-Marketing Pada Pelaku Usaha Industri Mikro Pengrajin Sepatu Di Kecamatan Medan Denai. Jurnal $\begin{array}{llll}\text { Pengabdian Kepada } & \text { Masyarakat, }\end{array}$ https://doi.org/10.24114/jpkm.v23i2.7028

Nirwana, Nihlatul Qudus Sukma, \& Biduri, Sarwendah. (2021). Implementasi Digital Marketing Pada UMKM Di Era Revolusi Industri 4.0 (Study Pada UMKM Di Kabupaten Sidoarjo). BALANCE: Economic, Business, Management and Accounting Journal. https://doi.org/10.30651/blc.v18i1.5720

Purnamaningsih, Putu Eka, \& Wirtya, I. Ketut. (2018). Implementasi Kebijakan Dinas Koperasi, UKM Dan Perindustrian Perdagangan Kota Denpasar (Studi Kasus Peningkatan Daya Saing UKM Dalam Menghadapi Masyarakat Ekonomi ASEAN). Jurnal Kependudukan Dan Pengembangan Sumber Daya Manusia.

Purwana, Dedi, Rahmi, R., \& Aditya, Shandy. (2017). Pemanfaatan Digital Marketing Bagi Usaha Mikro, Kecil, Dan Menengah (UMKM) Di Kelurahan Malaka Sari, Duren Sawit. Jurnal Pemberdayaan Masyarakat Madani (JPMM). https://doi.org/10.21009/jpmm.001.1.01

Sasongko, Dimas, Putri, Intan Rahma, Alfiani, Vivi Nur, Qiranti, Saskia Dyah, Sari, Riski Sinta, \& Allafa, Pramania Eka. (2020). Digital Marketing Sebagai Strategi Pemasaran UMKM Makaroni Bajak Laut Kabupaten Temanggung. Jurnal Ilmiah Pangabdhi. https://doi.org/10.21107/pangabdhi.v6i2.7809

Sedyastuti, Kristina. (2018). Analisis Pemberdayaan UMKM Dan Peningkatan Daya Saing Dalam Kancah Pasar Global. INOBIS: Jurnal Inovasi Bisnis Dan Manajemen Indonesia. https://doi.org/10.31842/jurnal-inobis.v2i1.65

Sugiyono. (2017). Metode Penelitian Kuantitatif Kualitatif \& RND. Bandung: Alfabeta.https://doi.org/10.31004/basicedu.v5i4.1235

Sugiyono. (2016). Sugiyono, Metode Penelitian. 
Dessica Dwiyuliana, Renie Dwi Sulistyani, Zulfikar Abdulah, Augustin Rina Herawati

Sugiyono.https://doi.org/10.21009/JPUD.102.04

Sukarsih, Icih, Kurniati, Eti, Gunawan, Gani, \& Wulan, Respita. (2016). Perluasan Jangkauan Pasar Pelaku UKM Sepatu Cibaduyut Melalui Pelatihan dan Pendampingan Internet Marketing. Ethos (Jurnal Penelitian Dan Pengabdian Masyarakat), 4.

Supriyati, Endang, \& Iqbal, M. (2013). (2013). Faktor Adopsi Internet Marketing Untuk Usaha Mikro dan Usaha Kecil Menengah (UMKM) di Kabupaten Kudus dengan SEM (Structural Equation Model) dan Framework Cobit 4.1. Simetris: Jurnal Teknik Mesin, Elektro dan Ilm. Simetris: Jurnal Teknik Mesin, Elektro Dan Ilmu Komputer, 3 . 